\title{
Sovereign Credit Rating Changes and its Impact on Financial Markets of Europe During Debt Crisis Period (Greece, Ireland)
}

Masood O, Bashir F* and Sahi Al

Lahore School of Accountancy, Lahore, Pakistan

\begin{abstract}
The purpose of this study is to examine the impact of sovereign credit rating changes on financial markets using database of two countries (Greece, Ireland) in the European union over the period March 2008-Dec 2015. By analyzing the influence of sovereign credit rating on bond market yield, we also examine the correlation between sovereign credit rating and bond market yield of each country during crisis period. Quarterly basis data of all variables is used in the research. By using regression analysis with Durbin Watson test and Pearson correlation for each country financial markets the findings indicated that sovereign credit rating has a significant impact on bond markets. Sovereign ratings are negatively correlated with Bond yield in both countries. The finding summarized that credit rating has a major influence on financial markets during crisis period.
\end{abstract}

Keywords: Credit ratings; Moody; S\&P; Fitch; Bond yield; Inflation; Current account

\section{Introduction}

"There are two superpowers in the world today in my opinion. There's the United States and there's Moody's Bond Rating Service. The United States can destroy you by dropping bombs, and Moody's can destroy you by downgrading your bonds. And believe me, it's not clear sometimes who is more powerful."

Thomas L. Friedman on 28 March 1999, in the New York Times Magazine.

The 1980 Latin American Financial crises, Asian financial crises in 1997, Russian debt crises in 1998, and recent Eurozone crises that started after US crises in 2008, demonstrated sovereign credit risk. When a Country unable to meet its financial obligations especially public debt, it means it may be default. This study explores the debt crisis and importance of credit ratings during financial crisis period.

Role of credit rating agencies in international financial markets

Credit rating agencies played a vital role in International markets. Many researchers examined the role of credit ratings using rating changes data of S\&P, Moody's and Fitch examined the contagion across securities \&countries. Its research confirmed the spillover among markets. Event study is used to examine the impact of credit ratings on stock market indices conveyed information that only downgraded in ratings have impact on financial markets [1]. By constructing Speculative market pressure index to examine rating impact on financial markets, they found that Sovereign rating changes and credit outlooks have a significant effect on the size and volatility in case of ratings downgrades and negative outlook [2].

\section{Credit rating agencies industry}

There are three rating agencies that captures the International financial markets: Moody's, S\&P, Fitch Moody was first rating agency that published its rating in 1909 while S\&P published its first ratings in 1923. In 1997-2000, Fitch came into being as a result of Merger between Fitch Investor services, IBCA \& Duff \& Phelps. Moody's \& S\&P have captured the market with $80 \%$ of all rating revenue. Fitch rating had successfully captured the niche market for third opinion on many obligors.

\section{Sovereign credit ratings history}

Modern sovereign ratings are a relatively new phenomenon. Moody started rated sovereigns in 1974, At First, Moody rated Canada, USA and Australia, and in 1975, S\&P rated only Canada and United States and the Predecessors Fitch posed no serious challenge to the industry duoply. Sovereign rating actively grew steadily through the 1980s, but their major focus was on the industrialized countries. In 1990, Sovereign ratings continued to flourish by which time emerging market and transition economics become the key source of growth. At the end of 2002, Moody had its public ratings on 109 Sovereign Governments, S\&P 93 and Fitch on 77. Generally, Sovereign rating downgrades are considered to be indications of crisis. Juttner and Mc [3] define rating as a three-notch Sovereign credit rating downgrade on long term foreign currency debt over any six month period.

\section{Sovereign credit rating criteria}

Sovereign credit ratings are assessments of likelihood that a borrower will default on her obligations and that is based on overall creditworthiness of a country. Credit rating agencies consider their ratings as forward indications of country risk that debt issuers will not able and willing to made payments of particular rated Instruments. Sovereign credit risk is categorized into two major components economic risk and political risk.

Economic risk tells about the ability of sovereign government to repay its obligations on time by considering the qualitative and quantitative factors. There are some determinants which is necessary

*Corresponding author: Fahad Bashir, Mphil Scholar, Lahore School of Accountancy, Lahore, Pakistan, Tel: +923338578128; E-mail: FahadBashir211@gmail.com

Received October 14, 2017; Accepted November 21, 2017; Published November 29, 2017

Citation: Masood O, Bashir F, Sahi Al (2017) Sovereign Credit Rating Changes and its Impact on Financial Markets of Europe During Debt Crisis Period (Greece, Ireland). J Bus Fin Aff 6: 304. doi: 10.4172/2167-0234.1000304

Copyright: (C) 2017 Masood O, et al. This is an open-access article distributed under the terms of the Creative Commons Attribution License, which permits unrestricted use, distribution, and reproduction in any medium, provided the original author and source are credited. 
to assess the solvency and liquidity of Sovereigns. For Example, S\&P divides these factors into eight categories: political risk, Income and economic structure, economic growth prospects, fiscal flexibility, public debt burden, price stability, balance of payments flexibility and external debt and liquidity (Appendix 1). Moody's and Fitch also consider the above factors to assess the country willingness or ability to pay its obligations.

\section{Sovereign credit rating system}

In order to assign their sovereign ratings, the credit ratings apply an ordinal scale. Sovereign credit ratings is divided into three broad categories (Appendix 2).

\section{Upper Investment Grade}

2. Lower Investment Grade

\section{Speculative Grade.}

Investment grade issues are considered acceptable for Institutional investors. Fitch and S\&P issues rated BBB- and above are as investment grade and Moody's split it at Baa3 and above. Sovereign ratings rules described in the research shows that S\&P and Fitch run from AAA, the highest through AAA up to BBB which is considered as Investment grade and then when it is going to be down at $\mathrm{D}$ which shows the potential default of a country. In contrast, Moody sovereign ratings range from "Aaa" category at the top $\mathrm{Ca}, \mathrm{Cc}, \mathrm{C}$ category at the last which is consider to be default. Different numeral values are assigned to these rating ranges from $\mathrm{A}$ to $\mathrm{D}$. Linear transformation scales are used for giving numeral values to ratings, they used values from 1 to 20 top value given to top rating and lowest to lowest ratings [2,4]. By using as a base (Yun Lai 2013): I assigned 0 value to D, 1 for C, 2 for $\mathrm{cc} /$ $\mathrm{ca}, 3$ for ccc-/caa3,4 for ccc/caa2,5 for ccc+/caa1,6 for B-/B,7 for B/B2,8 for $\mathrm{B}+/ \mathrm{B}, 9$ for $\mathrm{BB}-/ \mathrm{Baa} 3,10$ for $\mathrm{BB} / \mathrm{Ba}, 11$ for $\mathrm{BB}+/ \mathrm{Ba} 1,12$ for $\mathrm{BB}-/$ $\mathrm{Baa} 3,13$ for $\mathrm{BBB} / \mathrm{Baa} 2,14$ for $\mathrm{BBB}+/ \mathrm{Baa} 1,15$ for $\mathrm{A}-/ \mathrm{A} 3,16$ for $\mathrm{A} / \mathrm{A} 2,17$ for $\mathrm{A}+/ \mathrm{A} 1,18$ for $\mathrm{AA}-/ \mathrm{Aa} 3,19$ for $\mathrm{AA} / \mathrm{Aa} 2,20$ for $\mathrm{Aa} 1 / \mathrm{AA}+$ and 21 for AAA/Aaa. Long term foreign currency ratings and short term foreign currency ratings are used as a major variable in the research. So, I also assigned numeral values to short term ratings 0 for $\mathrm{D} / \mathrm{D}, 1$ for $\mathrm{C} / \mathrm{C}, 2$ for B/B, 3 for A-3/F3, 4 for F2/A-2, 5 for F1/A-1, and 6 for F1+/A-1+ (Appendix 3). Ordinal Scales of Credit rating agencies like "AAA" have a stronger capacity $t$ meet its financial obligations and "SD" means default. All the grades of credit rating agencies are detailed discussed in Appendixes 4 and 5.

In recent years, Credit rating agencies have divided their ratings into actual ratings and outlook/watch. And these ratings is further divided into long term ratings and short term ratings which are seen in both sense foreign and local currency ratings. There is no imminent difference while assigning foreign or local currency ratings so I used long term foreign currency ratings and short term foreign currency ratings as a major variable in this research. Three moderating variables Gdp, current account and inflation is used in my research.

\section{Objectives of research}

1: To examine the impact of sovereign credit ratings on financial markets during crises period.

2: To examine the significant impact of Sovereign credit ratings on Bond market yield of Greece, Ireland during financial crises period.

3: To investigate the correlation between sovereign credit ratings and bond yield during financial crises period.

\section{Literature Review}

Creighton et al. [5] analyzed the impact of rating changes in financial markets of Australia. Credit ratings changes information was taken from two leading rating agencies (S\&P, Moody's). Actual changes and credit watches were considered in the research. Data related bonds were taken from UBS Australia or Merrill Lynch. Time period of dataset covered from January 1990 to July 2003. Ordinary least square method and Standard deviation were used as an econometric tool in the research. The results stated that news about credit ratings had impact on both bond and equity prices in Australia. High bond spreads appeared in case of negative rating announcements and low spread in case of positive announcements. In case of ratings downgrades equity prices fall and in case of upgrades in ratings equity prices goes up. The study shows clear picture as compare to past researches that did not provide the clarification how credit ratings impacts on markets. In case of equity events they had a large sample size, and in case of bonds their focus was spreads rather than prices. But they found that agencies had no access to important information that was not in the public domain.

Christopher et al. [6] investigated the short terms and long terms effects of sovereign credit ratings on stock market and bond markets, and checked the correlations with their respective region markets for this research, they give a data set of nineteen emerging countries classified into four groups (ASIA) Europe, Latin America and Middle East/Africa over the period from $1^{\text {st }}$ January 1994 to $1^{\text {st }}$ July 2007. They found that there is a significant difference in effects of rating information on both bond and stock markets interrelated over different time period. Asset correlation is more liaison to ratings in long run then short run. So they observed that there is positive regional ratings and outlooks on stock markets co-movements if there is upgrade in ratings lead to higher return. In case of down grade, investors shifting funds from downgraded markets to nearest region on the other hand there is a negative regional ratings effects of sovereign ratings and out looks on bond co movements it mean when ratings and outlooks are revised downwards investors may be withdraw funds from nearest regions as well as downgraded markets when sovereign ratings improves investors shift funds from other bond markets in favor of affected markets and that give a result of fall in regional correlations.

Li et al. [7] examined the impact of changes in sovereign credit ratings and out looked on capital markets. The Study also explained the feedback of global bond and stock markets to credit rating changes also differentiate that feedback under macroeconomics and rating factors. For that purpose of research, they used a set of 34 countries including developed and emerging economies. Credit watch list issued by S\&P was used for data stream. The date of dataset starts from January 1 , 1990 and ends at June 30, 2000. Country's daily price indexes which we measured was in US Dollars and were collected from DataStream's Global Indices Section. The finding showed that credit rating agencies provide new beneficial information to financial markets. Credit rating announcements affects both bond and stock markets, but they react in different form. But positive reaction is linked with upgraded outlook in bond market only. The findings reflect that positive impact is significant for bond market returns. Downgraded ratings and economic outlook exists during bond market downturns raising a possibility that rating agencies may aggravate a bearish bond market. Analysis shows credit rating downgrades have a negative impact on stock market returns. Negative impact of credit rating downgrade on stock return was prominent in case of high rate of inflation, fiscal balances and sovereign debts etc. Credit rating downgrades on bond return shows negative impact in case of low inflation, and during non-crises period. 
Lee [4] conducted a research on sovereign rating changes and their impact on financial markets during crises period. Stock prices and Bond Yield is examined during study of that research. Effects of interest rates were also part of that research. Five Asian countries was included in the dataset of research and others are included on availability of data. They used JP Morgan global index for bond yield and country stock prices in local currency. Data regarding Sovereign credit ratings of Moody's, S\&P, and Fitch was taken from Bloomberg. Panel regression with different model is used as an econometric tool in that research. The findings stated that there is a strong evidence of sovereign credit rating news on own stock markets and bond yield spreads. That research also indicated foreign country effects of ratings downgrades in one country had a significant impact on stock prices as well as bond yield spread.

\section{Rating impact during crises periods}

Christopher et al. [6] analyzed the impact of credit rating agency announcements on the value of Euro and Yield of German, Italian, French and Spanish sovereign bonds during the euro zone debt crises in (2011-2012). Information regarding rating changes was taken from websites of rating agencies S\&P, Moody's, and Fitch's. They tested three types of events: watch, outlook and downgrade. Data regarding yield of bond was taken from each country's data stream. They adopted event study methodology along with GAARCH Model in order to examine the impact of rating announcements by credit rating (S\&P, Moody's \& Fitch's). Exchange rate Model and two CAPM models were used to explain sovereign bond yields for selected countries. The major findings of research were following: Credit rating Agency watch list and outlook events had no significant influence on the value of euro. However decrease in sovereign ratings had statistically impact because euro depreciates against other crises. Yield of French, Italian and Spanish Sovereign bonds increases but German bond yield decreases in case of credit rating downgrades. Sometimes volatility of euro exchange rates and sovereign bond yields increased due to CRA announcements that showed uncertainty in markets. However CRA announcements may had distributional effects.

\section{Sovereign market news impact on market volatility}

Afonso et al. [8] investigated the reaction of bond \& equity markets volatilities to sovereign ratings announcements (Moody's standard and poor, Fitch) using a panel of daily stock markets and bond market return they covered 21 EU countries data set starts from January 1995 to October 2011. It also covered the tenure of euro debt crises sovereign ratings announcements and ratings outlook changes is provided by three ratings agencies S\&P Moody's and Fitch. They used fixed effect analysis of EU stock market and bond market to see the impact of ratings agencies announcements on financial markets volatilities practically the also filtered the equity and bond return volatilities through EGAARCH models they also analyzed the information of sovereign downgrade and upgrade on these volatilities they concluded that sovereign ratings changes have lopsided effects on both bond and equity volatilities in fact upgrade ratings don't have any high effect on volatility, but downgrades rating increase stock market volatility moreover rating announcements create interlinked among European financial markets with upgrade in one country leadings to downgrade in volatility in other countries they also explained financial gains and risk reductions for portfolio returns [9].

\section{Research Methodology}

\section{Introduction}

This chapter presents the research methodology in order to conduct the research study. In our research we examined the impact of sovereign credit ratings on financial markets of two core countries namely Greece, Ireland of Europe that are badly affected during eurozone financial crises. Researchers have worked on that problem in many ways. Bheenick et al. [9] used various nonparametric tests like Kurtosis, skewness to develop the multivariate model and also used Granger Causality test to analyze the effects of credit ratings announcements on European stock market returns and currency markets. Kraussal [2] used Autocorrelation function (ACF), Augmented Dickey-Fuller (ADF) test, Jarque Bera test to investigate the impact of credit ratings on emerging markets. OLS with Standard deviation techniques used for analyzing the impact of credit rating announcements in Australian markets. Gower and Richards. Regression Analysis with EGAARCH Model is used for investigating the reaction of bond markets and equity markets volatility to sovereign rating announcements Afonso and Gomes. OLS Models with Bresusch Godfrey Durbin Watson test was used to examine the credit rating effects on banking sector of emerging markets. Norden and Weber [10] used separate regression models for stock markets and CDS to check the impact of rating announcements.

\section{Research hypothesis}

\section{For Greece}

$\mathrm{H}_{1}=$ There is significant impact of sovereign rating news on bond market yield of Greece during debt crises period.

$\mathrm{H}_{2}=$ There is no significant impact of sovereign rating news on bond market yield of Greece during debt crises period.

\section{For Ireland:}

$\mathrm{H}_{1}=$ There is significant impact of sovereign rating news on bond market yield of Ireland during debt crises period.

$\mathrm{H}_{2}=$ There is no significant impact of sovereign rating news on bond market yield of Ireland during debt crises period (Appendix 6).

\section{Description of data}

Data type: Dataset consists of Greece and Ireland. Secondary data is used for quantitative analyses to examine the impact of sovereign rating news on financial market of European countries during crises period. Data about all variables which are used in the research is included in Appendixes 7 and 8.

Sources of data: Dataset comprises of credit rating figures and information regarding indicators of financial markets. Data regarding rating news is taken from three leading credit rating companies (Moody's, S\&P, and Fitch websites) of the world, Countryeconomy. com and The Guardian.com. Data related to ten year Bond Yield is taken from website of economic research Federal Reserve Bank of St. Louis (FRED). Data related to/moderating variables is taken from Imf, OECD and European central bank website. Data related to inflation of European countries is taken from the website http://www.inflation.eu.

Time horizon: We examined the sovereign rating changes and their impact on five countries over the period of 2008-2015. Because Effects of Global crises exist in that period and European crises was started from 2009 in Greece; therefore, I selected that time period in my research.

\section{Research models}

Regression analysis with explanation: Different econometric models are used in research. In this research we used Linear Multiple Regression model with Pearson correlation. Regression analysis is that 
model which is used to check the impact of independent variables on the dependent variables. Sovereign Long term and Short term foreign currency is used as an independent variable in the research. We measured the impact of sovereign ratings on bond markets during crisis period.

$$
\mathrm{BYD}=\mathrm{a}+\beta 1 \mathrm{LFC}+\beta_{2 \mathrm{SFC}}+\beta_{3} \operatorname{Inf}+\beta_{3} \mathrm{Gdp}+\beta_{3} \mathrm{Gdp} \varepsilon \mathrm{i}
$$

The Regression Equation is given below for Bond markets:

$$
\mathrm{Y}=\alpha+\beta 1 \mathrm{X}_{1}+\beta_{2} \mathrm{X}_{2}+\beta_{3} \mathrm{X}_{3}+\varepsilon \mathrm{i}
$$

Where, $\mathrm{Y}=$ Bond market Yield (dependent variable)

$\mathrm{X}_{1}=$ Long term foreign currency ratings (independent variable)

$\mathrm{X}_{2}=$ Short term Foreign currency ratings (independent variable)

$\mathrm{X}_{3}=\mathrm{Gdp}$ real Index (Moderating Variable)

$\mathrm{X} 4=\mathrm{CPI}$ inflation (Moderating Variable)

$\mathrm{X} 5=$ Current account to Gdp(Moderating Variable)

$\alpha=$ Constant

$\mathrm{c}=$ Regression Coefficient

$\mathcal{E} \mathrm{i}=$ Error arising due to other variables

$\mathrm{STR}=\mathrm{a}+\beta_{1} \mathrm{LFC}+\beta_{1} \mathrm{SFC}+\beta_{3} \mathrm{Inf}+\beta_{3} \mathrm{Gdp}+\beta_{3} \mathrm{CA}+\varepsilon \mathrm{Ei}$

Durbin-Watson test: Durbin Watson test is used to check the multicollinerity between independent variables. If the value of $\mathrm{D}-\mathrm{W}$ is equal to 2 it means there is no collinearity between two variables if it exceeds up to 4 . It means there is collinearity between variables which is harmful for research.

Pearson correlation: Correlation analysis is used to determine the relationship between variables. This research tool measures of how two variables move in relation to each other. Correlation is used in advance portfolio management.

Correlation Coefficient is computed into what is known as the correlation coefficient. Which ranges between -1 to +1 . Value of correlation co-efficient +1 describes that one security moves up or down other will also moves in same direction. And value of correlation coefficient - 1 describes if one security moves in up direction other will moves in opposite direction. If results of correlation coefficient will be zero it means there is no correlation between variables that are used in the research.

\section{Data Analysis and Results}

The results of Table 1 represents about correlation coefficient $r$ which is equivalent to 0.886 and coefficient of determination $r^{2}$ value is equivalent to 0.784 it represents that $78.4 \%$ of variation in Bond yield is explained by Long term foreign currency rating, short term ratings and other three moderating variables current account, inflation and Gdp. Durbin Watson test is used to check the multicollinerity about independent variables its value is equivalent to 1.318 which shows there is no autocorrelation among variables. The result also represents the significance level of model. It shows the value of significance is 0.000 which is less than 0.01 . It means modal is more significant at 0.01 level. F statistic shows that significance of overall model. The value of $\mathrm{F}$ is 18.899 .

$\mathrm{BYD}=15.219-0.2399 \mathrm{LFC}-1.689 \mathrm{SFC}+235.831 \mathrm{INF}-0.793 \mathrm{GDP}-$ 0.178 CA.

Here, $\mathrm{a}=15.219$ and its significance value is equivalent to $0.000<0.01$ whish shows that constant value is significant at 0.01 level. $\beta 1$ shows that with unit change in long term foreign currency rating then stock market returns are decreased by -0.239 and its significance value is 0.720 which shows the negatively impact on market. $\beta 2$ shows that with a unit change in short term ratings return will decrease by -1.689 its significance value is $0.172>0.05$ which shows that it has negative impact on market. $\beta 3$ shows that with unit change in inflation returns is decreased by 235.831 which is highly insignificant with value 0.386 . $\beta 4$ represents Gdp with unit change returns also changed by -0.793 its value of significant at $0.001<0.05$. $\beta 5$ shows with the change of unit of current account return is also changed by -0.178 its value of significance is $0.848>0.05$ level but it has negative impact on bond market yield. Probability value of $\mathrm{F}$ is less than $5 \%$ it means whole model is significant and F statistic also shows the fitness of model (Table 2).

Table 3 results shows that a correlation between STR and LFC is -0.648 which is negatively correlated with each other but there is strong negative correlation among these variables with the value of significance at $0.000<0.001$. Short term ratings -0.693 and returns shows strong but negatively correlation among each other with the value of significance at $0.000<0.001$. Correlation between inflation and SSTR is equivalent to -0.042 which shows negative correlation between these variables. Gdp and BYD has also strongly negative correlation among each other with a value of -0.631 with value of significance at $0.000<0.001$. While current account and BYD has weak positively correlation among each other with the value of 0.265 at 0.071 significant value which is insignificant at $5 \%$ level. Pearson correlation signifies that there is indirect correlation among long term ratings inflation Gdp short term rating and bond yield while direct correlation with current account of Greece among bond yield.

Table 4 results represents about correlation coefficient $r$ which is equivalent to 0.631 and coefficient of determination $r^{2}$ value is equivalent to 0.398 it represent that $39.8 \%$ of variation in Bond yield is explained by Long term foreign currency rating, short term ratings and other three moderating variables current account, inflation and Gdp. Durbin Watson test is used to check the multicollinerity about independent variables its value is equivalent to 0.598 which shows there is no autocorrelation among variables. The result also represents the significance level of model. It shows the value of significance is 0.016 which is less than 0.05 . It means model is significant at 0.05 level. $\mathrm{F}$ statistic shows that significance of overall model. The value of $\mathrm{F}$ is 3.436 .

$\mathrm{BYD}=15.315-0.122 \mathrm{LFC}-1.350 \mathrm{SFC}-60.903 \mathrm{INF}-0.411 \mathrm{GDP}-$ $0.423 \mathrm{CA}$.

\begin{tabular}{|c|c|c|c|c|c|c|c|c|c|c|}
\hline \multicolumn{11}{|c|}{ Model Summary } \\
\hline \multirow[t]{2}{*}{ Model } & \multirow[t]{2}{*}{$\mathrm{R}$} & \multirow[t]{2}{*}{$\mathrm{R}$ Square } & \multirow[t]{2}{*}{ Adjusted R Square } & \multirow[t]{2}{*}{ Std. Error of the Estimate } & \multicolumn{5}{|c|}{ Change Statistics } & \multirow[t]{2}{*}{ Durbin-Watson } \\
\hline & & & & & R Square Change & F Change & df1 & df2 & Sig. F Change & \\
\hline 1 & $.886^{a}$ & 0.784 & 0.743 & 3.124119 & 0.784 & 18.899 & 5 & 26 & 0 & 1.318 \\
\hline
\end{tabular}

Here $\mathrm{a}=15.315$ and its significance value is equivalent to $0.001<0.05$

a. Predictors: (Constant), CA, GDP, INF, SFC, LFC

Table 1: Greece bond market results and its interpretation. 
Citation: Masood O, Bashir F, Sahi Al (2017) Sovereign Credit Rating Changes and its Impact on Financial Markets of Europe During Debt Crisis Period (Greece, Ireland). J Bus Fin Aff 6: 304. doi: 10.4172/2167-0234.1000304

Page 5 of 7

\begin{tabular}{|c|c|c|c|c|c|c|}
\hline \multicolumn{7}{|c|}{ Coefficients } \\
\hline & \multirow[t]{2}{*}{ Model } & \multicolumn{2}{|c|}{ Unstandardized Coefficients } & \multirow{2}{*}{$\begin{array}{c}\text { Standardized Coefficients } \\
\text { Beta }\end{array}$} & \multirow[t]{2}{*}{$\mathbf{t}$} & \multirow[t]{2}{*}{ Sig. } \\
\hline & & B & Std. Error & & & \\
\hline \multirow[t]{6}{*}{1} & (Constant) & 15.219 & 1.58 & & 9.63 & 0 \\
\hline & LFC & -0.239 & 0.66 & -0.202 & -0.363 & 0.72 \\
\hline & SFC & -1.689 & 1.204 & -0.519 & -1.403 & 0.172 \\
\hline & INF & 235.831 & 267.431 & 0.105 & 0.882 & 0.386 \\
\hline & GDP & -0.793 & 0.203 & -0.497 & -3.909 & 0.001 \\
\hline & CA & -0.178 & 0.922 & -0.058 & -0.193 & 0.848 \\
\hline
\end{tabular}

Table 2: Stock market coefficient.

\begin{tabular}{|c|c|c|c|c|c|c|c|}
\hline \multicolumn{8}{|c|}{ Correlations } \\
\hline & & BYD & LFC & SFC & INF & GDP & CA \\
\hline \multirow[t]{6}{*}{ Pearson Correlation } & BYD & 1.000 & -0.648 & -0.693 & -0.042 & -0.631 & 0.265 \\
\hline & LFC & -0.648 & 1.000 & 0.930 & 0.480 & 0.124 & -0.822 \\
\hline & SFC & -0.693 & 0.930 & 1.000 & 0.412 & 0.132 & -0.635 \\
\hline & INF & -0.042 & 0.480 & 0.412 & 1.000 & -0.259 & -0.611 \\
\hline & GDP & -0.631 & 0.124 & 0.132 & -0.259 & 1.000 & 0.217 \\
\hline & CA & 0.265 & -0.822 & -0.635 & -0.611 & 0.217 & 1.000 \\
\hline \multirow[t]{6}{*}{ Sig. (1-tailed) } & BYD & - & 0.000 & 0.000 & 0.411 & 0.000 & 0.071 \\
\hline & LFC & 0.000 & - & 0.000 & 0.003 & 0.249 & 0.000 \\
\hline & SFC & 0.000 & 0.000 & - & 0.010 & 0.235 & 0.000 \\
\hline & INF & 0.411 & 0.003 & 0.010 & - & 0.076 & 0.000 \\
\hline & GDP & 0.000 & 0.249 & 0.235 & 0.076 & - & 0.116 \\
\hline & CA & 0.071 & 0.000 & 0.000 & 0.000 & 0.116 & - \\
\hline \multirow[t]{6}{*}{$\mathrm{N}$} & BYD & 32 & 32 & 32 & 32 & 32 & 32 \\
\hline & LFC & 32 & 32 & 32 & 32 & 32 & 32 \\
\hline & SFC & 32 & 32 & 32 & 32 & 32 & 32 \\
\hline & INF & 32 & 32 & 32 & 32 & 32 & 32 \\
\hline & GDP & 32 & 32 & 32 & 32 & 32 & 32 \\
\hline & $\mathrm{CA}$ & 32 & 32 & 32 & 32 & 32 & 32 \\
\hline
\end{tabular}

Table 3: Correlation between STR and LFC.

\begin{tabular}{|c|c|c|c|c|c|c|c|c|c|c|}
\hline \multicolumn{11}{|c|}{ Model Summary } \\
\hline \multirow[t]{2}{*}{ Model } & \multirow[t]{2}{*}{$\mathbf{R}$} & \multirow[t]{2}{*}{ R Square } & \multirow[t]{2}{*}{ Adjusted R Square } & \multirow{2}{*}{$\begin{array}{l}\text { Std. Error of the } \\
\text { Estimate }\end{array}$} & \multicolumn{5}{|c|}{ Change Statistics } & \multirow[t]{2}{*}{ Durbin-Watson } \\
\hline & & & & & R Square Change & F Change & df1 & df2 & Sig. F Change & \\
\hline 1 & $.631^{\mathrm{a}}$ & 0.398 & 0.282 & 2.144768 & 0.398 & 3.436 & 5 & 26 & 0.016 & 0.598 \\
\hline
\end{tabular}

a.Predictors: (Constant), CA, INF, GDP, SFC, LFC

Table 4: Ireland bond market results and its interpretation.

\begin{tabular}{|c|c|c|c|c|c|c|}
\hline \multicolumn{7}{|c|}{ Coefficients } \\
\hline \multirow{2}{*}{\multicolumn{2}{|c|}{ Model }} & \multicolumn{2}{|c|}{ Unstandardized Coefficients } & \multirow{3}{*}{$\begin{array}{c}\text { Standardized Coefficients } \\
\text { Beta }\end{array}$} & \multirow[t]{2}{*}{$\mathbf{t}$} & \multirow[t]{2}{*}{ Sig. } \\
\hline & & B & Std. Error & & & \\
\hline \multirow[t]{6}{*}{1} & (Constant) & 15.315 & 3.984 & & 3.844 & .001 \\
\hline & LFC & -.122 & .695 & -.151 & -.175 & .863 \\
\hline & SFC & -1.350 & 2.049 & -.475 & -.659 & .516 \\
\hline & INF & -60.903 & 143.608 & -.075 & -.424 & .675 \\
\hline & GDP & -.411 & .165 & -.415 & -2.493 & .019 \\
\hline & $\mathrm{CA}$ & -.423 & .211 & -.589 & -2.006 & .055 \\
\hline
\end{tabular}

Table 5: Statistics of Coefficients and its interpretation

whish shows that constant value is significant at 0.05 level. $\beta 1$ shows that with unit change in long term foreign currency rating then stock market returns are decreased by -0.122 and its significance value is 0.863 which shows the negatively impact on market. $\beta 2$ shows that with a unit change in short term ratings return will decrease by -0.1 .350 its significance value is $0.516>0.05$ which shows that it has negative impact on market. $\beta 3$ shows that with unit change in inflation returns is decreased by -60.903 which is insignificant with value 0.675 . $\beta 4$ represents Gdp with unit change returns also changed by -0.411 its value of significant at $0.019<0.05$. $\beta 5$ shows with the change of unit of current account return is also changed by -0.411 its value of significance is $0.05=0.05$ level is slightly significant at 0.05 level. Probability value of $\mathrm{F}$ is less than $5 \%$ it means whole model is significant and $\mathrm{F}$ statistic also shows the fitness of model (Table 5).

Table 6 results shows that a correlation between STR and LFC is -0.060 which is negatively correlated with each other, but there is weak negative correlation among these variables with the value of significance at 0.373 which is insignificant at 0.05 level. Short term ratings -0.15 and yield shows strong but negatively correlation among each other with the value of significance 0.203 which is insignificant at 0.05 level. Correlation between inflation and yield is equivalent to 0.191 


\begin{tabular}{|c|c|c|c|c|c|c|c|}
\hline \multicolumn{8}{|c|}{ Correlations } \\
\hline & & BYD & LFC & SFC & INF & GDP & CA \\
\hline \multirow[t]{6}{*}{ Pearson Correlation } & BYD & 1.000 & -0.060 & -0.152 & 0.191 & -0.454 & -0.243 \\
\hline & LFC & -0.060 & 1.000 & 0.969 & -0.250 & -0.186 & -0.775 \\
\hline & SFC & -0.152 & 0.969 & 1.000 & -0.257 & -0.118 & -0.681 \\
\hline & INF & 0.191 & -0.250 & -0.257 & 1.000 & -0.203 & -0.038 \\
\hline & GDP & -0.454 & -0.186 & -0.118 & -0.203 & 1.000 & 0.235 \\
\hline & $\mathrm{CA}$ & -0.243 & -0.775 & -0.681 & -0.038 & 0.235 & 1.000 \\
\hline \multirow[t]{6}{*}{ Sig. (1-tailed) } & BYD & . & 0.373 & 0.203 & 0.147 & 0.005 & 0.091 \\
\hline & LFC & 0.373 & . & 0.000 & 0.084 & 0.154 & 0.000 \\
\hline & SFC & 0.203 & 0.000 & . & 0.078 & 0.260 & 0.000 \\
\hline & INF & 0.147 & 0.084 & 0.078 & . & 0.132 & 0.418 \\
\hline & GDP & 0.005 & 0.154 & 0.260 & 0.132 & . & 0.097 \\
\hline & $\mathrm{CA}$ & 0.091 & 0.000 & 0.000 & 0.418 & 0.097 & . \\
\hline \multirow[t]{6}{*}{$\mathrm{N}$} & BYD & 32 & 32 & 32 & 32 & 32 & 32 \\
\hline & LFC & 32 & 32 & 32 & 32 & 32 & 32 \\
\hline & SFC & 32 & 32 & 32 & 32 & 32 & 32 \\
\hline & INF & 32 & 32 & 32 & 32 & 32 & 32 \\
\hline & GDP & 32 & 32 & 32 & 32 & 32 & 32 \\
\hline & CA & 32 & 32 & 32 & 32 & 32 & 32 \\
\hline
\end{tabular}

Table 6: Correlation between inflation and yield.

which shows the positive correlation between these variables. Gdp and BYD has also strongly negative correlation among each other with a value of -0.454 with value of significance at 0.005 which is significant at 0.05 level. While current account and BYD has negatively correlation among each other with the value of -0.243 at 0.091 significant value which is significant at $0.1 \%$ level. Pearson correlation signifies that there is indirect correlation among long term ratings Gdp short term rating, current account and bond yield while direct correlation with inflation of Ireland among bond yield (Table 6).

\section{Conclusion and Recommendations}

\section{Greece concluding remarks}

In case of Bond markets, ten year bond yield is used as a dependent variable because it is used as a benchmark in Greece. The findings of research reject the null hypothesis and confirmed that p-value of Model is $0.000<0.01$ shows that model is highly significant at 0.01 level. By using Pearson correlation, it is concluded by findings there is negative correlation among sovereign credit ratings and bond Yield. If sovereign credit ratings downgrades Bond yield moves to up. As Creighton et al. [5] confirmed that high bond spread appears while negative rating announcements and low bond spread in case of positive rating announcements.

\section{Ireland concluding remarks}

In case of Bond markets ten year bond yield is used as a dependent variable because it is used as a benchmark in Ireland. The findings of research reject the null hypothesis and confirmed that p-value of Model is $0.016<0.05$ shows that model is highly significant at 0.05 level. By using Pearson correlation it is concluded by findings there is negative correlation among sovereign credit ratings and bond Yield. If sovereign credit ratings downgrades Bond yield moves to up. In moderating variables Gdp is perfectly negative correlated with yield. As Creighton et al. [5] confirmed that high bond spread appears while negative rating announcements and low bond spread in case of positive rating announcements. The findings describe that sovereign credit ratings along with its moderating variables play an important role in secondary markets during crises period.

\section{Recommendations of study}

At the end, it is concluded that credit ratings have a much power to influence the secondary markets.

- In Greece by getting bailouts their Leadership fails to overcome the financial crisis financial markets of Greece are affected by rating announcements and these procyclical effects transfer to other countries.

- By observing Ireland economy, It is concluded that their financial markets don't have power to absorb the reaction of announcements during crisis period. Financial markets shows instability during crisis period.

\section{Implications and future research}

Further in future this study may be extended by examining the contagion effect among markets and to examine the cross country correlation among markets by considering pre and post time period of financial crises. It might be a better approach to decide the role of credit ratings and to check the spillover among markets during crises period. It may be extended to foreign exchange and derivatives markets.

\section{References}

1. Brooks R, Fatt RW, Hiller D, Hillier J (2004) The national market impact of sovereign rating changes. Journal of Banking and Finance 28: 233-250.

2. KraussI R (2005) Do Credit Rating Agencies Add to The Dynamics of Emerging Market Crises? Journal of Financial Stability 1: 355-385.

3. Juttner JD, Mc J (2000) Modeling a Rating Crisis. Macquarie University, Sydney.

4. Lee EW (2003) Sovereign rating changes and Finanial Markets during the Asian Crisis.

5. Creighton A, Gower L, Richards AJ (2007) The impact of rating changes in Australian financial markets. Pacific-Basin Finance Journal 15: 1-17.

6. Christopher R, Kim SJ, Wu E (2012) Do sovereign credit ratings influence regional stock and bond market interdependencies in emerging countries? Journal of International Financial Markets Institutions \& Money 22: 1070-1089.

7. Li H, Jeon BN, Cho SY, Chiang TC (2008) The impact of sovereign rating changes and financial contagion on stock market returns: Evidence from five Asian countries. Global Finance Journal 19: 46-55. 
Citation: Masood O, Bashir F, Sahi Al (2017) Sovereign Credit Rating Changes and its Impact on Financial Markets of Europe During Debt Crisis Period (Greece, Ireland). J Bus Fin Aff 6: 304. doi: 10.4172/2167-0234.1000304

Page 7 of 7

8. Afonso A, Gomes P, Taamoutic A (2014) Sovereign credit ratings, market volatility, and financial gains. Computational Statistics and Data Analysis 76 : 20-33
9. Bheenick EB, Brooks R, Treepongkaruna S (2014) Rating spillover effects on the stock markets. J Multi Fin Manag, pp: 25-26.

10. Norden L, Weber M (2004) Informational efficiency of credit default. International Review of Accounting, Banking and Finance 1: 22. 